悪性線維性組織球腫様の組織像を呈した 乳腺再発悪性葉状腫瘍の 1 例

\begin{tabular}{lllllllll}
\multicolumn{10}{c}{ 市立伊丹病院外科 } \\
国府 育 央 4 本 正之 & 秋 & 洋 & 介 \\
山 田 克 & 平 位 洋 文 & 北 野 & 秀 & 武
\end{tabular}

悪性線維性組織球腫様の組織像を呈した再発覀性葉状腫場の 1 例を報告する.

症例は，53歳，女性. 良性の葉状腫瘍にて，腫場摘出術，広背筋弁形成術を施行した。 術後 3 カ月より腫瘍摘出部に硬結を触知し痛みが出現した，細胞診を数回施行したが血 液成分のみで, 超音波検査, CT 検査でも血腫疑いであり経過観察していたが, 細胞診穿 刺部の皮庯が発赤し硬結を触知したので生検を施行した。核分裂像, 細胞異型が中程度 認められ境界病変の葉状腫湯と診断し, 大胸筋への浸潤を疑い乳切術を施行した。病理 組織学的所見は, 紡鍾形の細胞が storiform pattern を形成し, 多形性の腫瑒細胞が認め られ, 細胞密度も高く核分裂像も認められた。また異型を伴わない上皮も認められ, 悪 性線維性組織球腫様の組織像を呈する悪性葉状腫煌と診断した. 術後 3 力月目に上腕骨 の病的骨折をきたし, 化学療法を施行したが, その後肺転移, 肝転移をきたし，8カ月 目に原病死した。

索引用語：悪性葉状腫瘍, 乳腺覀性線維性組織球腫, 葉状腫瘍再発

\section{はじめに}

葉状腫場は，中年女性に好発し，葉状の形態をとる ことにより葉状萁胞肉腫として報告されてきたが，そ の名称より良性, 悪性の混乱が生じたために現在では 肉腫という名称は使用せずに葉状腫瘍として一括し, そのなかで良性, 悪性と区別されている. 悪性葉状腫 瘍は, 上皮成分は悪性像を示さず, 間質成分のみが悪 性化したものであるが，今回間質成分が悪性線維性組 織球腫 (以下 $\mathrm{MFH}$ と略す) 様の組織像を呈した 1 例 を経験したので, 若干の文献的考察を加えて報告する.

$$
\text { 症例 }
$$

患者：53歳，女性。

主訴: 右乳房腫瘤.

既往歴・家族歴：特記すべきことなし.

現病歴: 平成 7 年 3 月 2 日葉状腫瘍 $(8 \times 8 \mathrm{~cm})$ にて, 腫瘍摘出術, また欠損部に広背筋弁形成術を施行した。 その後外来通院していたが，6月ごろより創部に硬結 を触知し痛みが出現した．細胞診を数回行ったが血液 成分のみであり, 超音波検査, $\mathrm{CT}$ 検査でも血腫疑いで

1997年 1 月22日受付 1997 年 4 月14日採用
あり経過観察していたが, 穿刺部の皮虍が発赤し, 直 下に腫瘤を触知したので，9月27日に生検を施行. 再 発と診断し，根治術目的にて11月30日当科入院となっ た。

病理組織学的所見：初回手術時は, 上皮に異型は認 められず, 間質成分が浮腫状に增殖し, 細胞密度は疎 であり, 細胞異型, 核分裂像は, 認められず良性の葉 状腫瘍と診断した(図 1). 生検時の組織像では, 以前 に比べ細胞密度が高く, 核分裂は10HPFで 8 個であり 細胞異型も中程度認められ境界病変の葉状腫瘍と診断 した")(図 2).

入院後経過 : CEA, CA15-3, NCC-ST439は正常で あったが, 肝機能が高值を示し, 検査にて A 型肝炎と 診断し手術を延期した。 その後肝機能が改善し, 平成 8 年 2 月27日に手術を施行した。その間に腫瘍は増大 傾向を示し，大胸筋への浸潤が疑われ，また腋窩りン パ節も触知したので, 乳房, 大胸筋切除, 腋窝郭清を 施行した，摘出腫瘍の大きさは， $6.0 \times 5.5 \times 3.5 \mathrm{~cm} て$ あった。病理組織学的検查では, 線維芽細胞様の紡錘 形細胞が storiform pattern を形成し多形性の腫湟細 胞や類円形の組織球様細胞も認められた。細胞密度も 


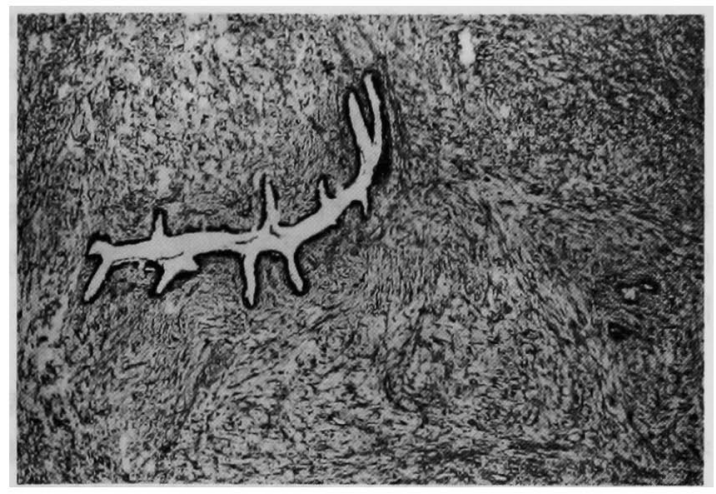

図 1 初回手術時病理組織学的所見: 間質成分が浮腫 状に增殖し，細胞密度は疎て，細胞異型，核分裂像， 上皮の異型は認められなかった（HE 染色，×100)。

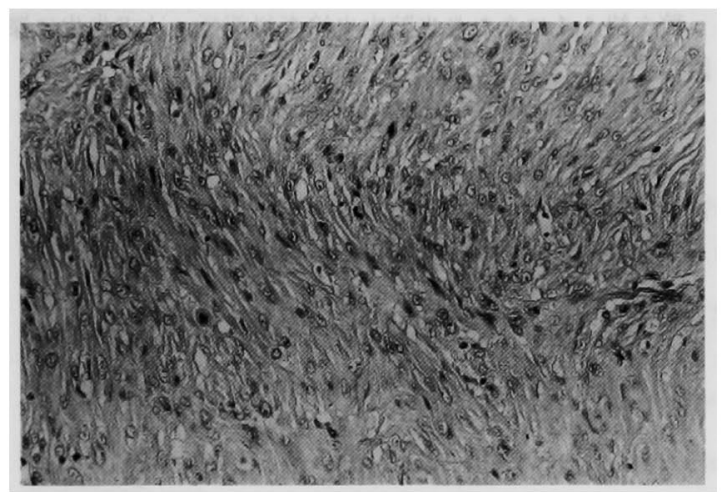

図2生検時病理組織学的所見：細胞密度は高く, 中 程度の細胞異型と核分裂像が認められた（HE 染 色, × 200)。

かなり高く，核分裂像は，10HPF あたり25個であり， 異型のない上皮も認められた。 以上より間質成分に MFH 様を呈する悪性葉状腫瘍と診断した（図 3).大 胸筋との境界は一部が infiltrative margin であり，リ ンパ節転移は認められなかった。

術後経過：患者は, 術後 3 力月目に上腕骨の病的骨 折をきたし，観血的整復術を施行した。その際病変部 に MFH 像が認められた。その後パミドロン酸二ナト リウムを含む化学療法を施行したが肺転移, 肝転移を きたし術後 8 力月目に原病死した。

考察

葉状腫場は，乳腺腫貆の約 $1 \%$ をしめる比較的稀な 腫瘍である，40代に好発しやすく，発育は普通は緩徐 であるが，急激に大きくなるものもある．腫瘍径の平 均は $4 \sim 7 \mathrm{~cm}$ との報告が多いがなかには $40 \mathrm{~cm}$ を越え るものもある ${ }^{11 \sim 4)}$. 葉状腫瘍は, 良性, 境界病変, 悪性

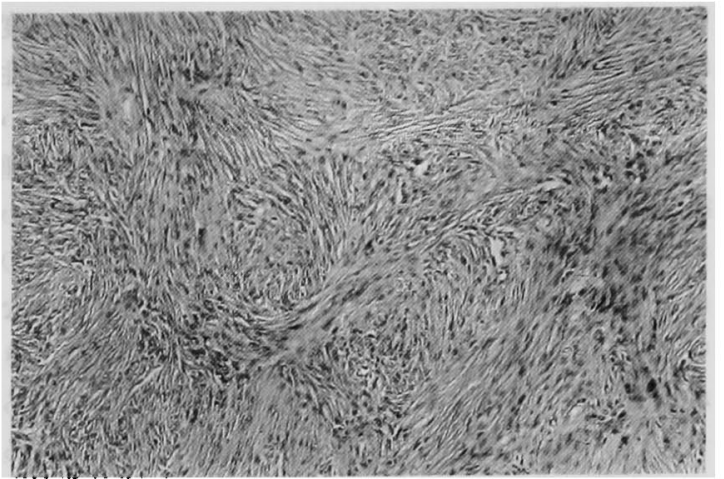

図 3 手術時病理組織学的所見：線維芽細胞様の紡鉂 形細胞が storiform pattern を形成し，細胞密度は 非常に高く, 紐胞異型, 核行裂像もかなり認められ た (HE 染色, $\times 100)$.

と区別されるが，26\% 45\%に悪性が認められると報 告されている(1) . 悪性葉状腫瘍は, 上皮成分は悪性像 を示さず間質成分が悪性化したものであるが，猃断に 関しては現在のところ統一された基準はなく Norris \& Taylor ${ }^{7}$, Pietruszka")らのものが幅広く用いられ ており, 細胞密度, 細胞異型, 核分裂の数, 周囲への 浸潤形態, 間質の一方的増殖, 壊死の有無などを組み 合わせ総合的に悪性の判定を行っている. 悪性葉状腫 瘍では間質は線維肉腫様の形態をとるが, 腫瘍組織が 軟骨, 骨, 脂肪, 平滑筋あるいは横紋筋への分化を示 すことがあり，また MFH の組織像に似ることもあ $ろ^{81}$. 自験例も一部に萎縮した腺管構造をみるが, 大部 分は $\mathrm{MFH}$ であった. $\mathrm{MFH}$ の像をしめす悪性葉状腫 瘍の報告例は少なく本邦では 2 例のみであり ${ }^{9120)}$, 海 外でも間質の分化の記載は少なく 4 例のみであっ $た^{3 / 11)}$.

治療に関しては, 化学療法の有効例の報告もある が3112〉一般的には効果はなく, 補助療法も現在のとこ ろその有用性は確立されていない。また内分泌療法, 放射線療法は効果がないとされ, 確実な外科的切除の みが唯一の治療法である。術式は局所切除から定型的 乳房切断術と幅広く行われており, 悪性では周囲への 浸潤がみられ境界が不明瞭なことが多く、乳切術では 再発は低く局所切除では再発が高くなるという報告が 多(22)5/6). 自験例では $6 \mathrm{~cm}$ を越える再発症例であり,大 胸筋への浸潤も考えられたので乳切術を行った. 局所 再発の頻度は， $5.5 \%$ 36\%とばらつきがみられる が(1 613)14，これは診断, 術式のちがいによるものと思 われる。また, 再発後の組織像は原発巣と同じことが 
多いが自験例のように悪性化するものもありその頻度 は， $8 \%$ 40\%と報告されている344)14). しかし, 悪性 も良性も再発率に差はなく", 術式は予後と関係ない とする報告も多く2)15), 術式の決定は良性, 悪性より腫 瘍自体の大きさで決めるとの意見が多(4) -8).すなわ ち, 腫湟径が小さいものは wide excision, 大きいもの は simple mastectomyを行いリンパ節郭清は必要な いとされている.また再発例も同様で確実に切除でき れば乳切術の必要はなく wide excisionで十分である とされ，実際に数回の再切除を行い長期生存している 例も数多く報告されている(13)413144).

転移に関しては，1例のみ上皮成分の転移が認めら

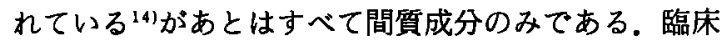
的に腋沼リンパ節転移を疑ったものでも，実際のリン 八゚節転移は稀である゙2. 遠隔転移は血行性であり，肺が 最も多く次いで骨に多く，その頻度は $4 \%$ \% $35 \%$ と報 告されている(1 6)13). MFH 像を呈するものは, 全身に 広範な転移をきたすことが多い91-11). 予後に関して は, 乳腺 MFH は四肢の MFH に比へ比較的良好であ

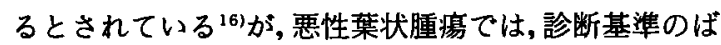
らつきもあり単純な比較は困難であるが遠隔転移例の 予後は, きわめて不良であり, 転移してからは, $3 \sim 10$ 力月で死亡する例が多く2131), 自験例も骨転移後 3 力 月で死亡している，予後因子としては，再発をきたす 因子は, 臨床, 病理学的に特になく, 不適切な手術の みである(15)13)が，転移をきたす因子は，腫煬の大きさ など臨床的な因子はなく，病理学的因子として間質の 一方的増殖, 核分裂の数, 細胞異型, 周囲への浸潤な どいろいろ報告されている(26)が, Hawkins ら ${ }^{3)}$, Ward ら (3)は間質の一方的増殖が最も重要であると述へてい るが, 詳細な病理学的検索が行われているかどうか施 設間のばらつきもあり意見の分かれるところである.

また, 悪性葉状腫場では病理学的診断と臨床経過が 相関しないことがしられている.病理学的に悪性と診 断されても局所切除のみで再発することなく数十年経 過している例も多くみられている。これは悪性の診断 が各施設間で統一されておらず，また詳細な病理学的 検索の有無によるものであるが, E1-Naggar ら ${ }^{15}$ は， DNA content を検索し, 線維腺腫はすべて diploid patternであり，葉状腫場のうち aneuploid patternを 示すものはきわめて予後が悪く, 組織学的ではなく臨 床的な悪性度を示しており，診断の補助になりうると

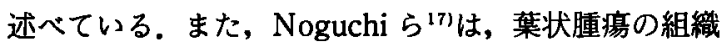
発生について，間質は monoclonal であり腫瘍性であ
るが, 組織学的に類似している線維腺腫は大多数は polyclonalであり過形成性であると述へている.しか し, 少数であるが monoclonal な線維腺腫も認められ これらは葉状腫場に転化することがあり，葉状嗹瘍に 準じ切除が望ましいと述べている。葉状腫愓は, 臨床 的に線維腺腫と区別がつきにくく，確実かつ適切な切 除が望まれる。

\section{おわりに}

悪性線維性組織球腫様の組織像を呈した再発悪性葉 状腫湯の 1 例を経験したので報告した．悪性葉状腫瘍 は，診断基準も一定でなく，転移例の予後は不良であ り，的確な診断とそれに応じた治療が望まれる。

本論文の要旨は第58回日本臨床外科医学会総会 (京都) で 発表した.

稿を終えるにあたり当院中央検查科部長, 过求先生に深 謝します。

\section{文献}

1) Pietruszka M, Barnes L: Cystosarcoma phyllodes, A clinicopathologic analysis of 42 cases. Cancer $41: 1974-1983,1978$

2) Reinfuss M, Mitus J, Smolak K, et al: Malig. nant phyllodes tumors of the breast. A clinical and pathological analysis of 55 cases. Eur $\mathrm{J}$ Cancer 29A : 1252-1256, 1993

3) Hawkins RE, Schofield JB, Fischer C, et al: The clinical and histologic criteria that predict metastases from cystosarcoma phyllodes. Cancer $69: 141-147,1992$

4) Grimes MM : Cystosarcoma phyllodes of the breast: Histologic features, flow cytometric analysis, and clinical correlations. Mod Pathol 5 : 232-239, 1992

5) Ciatto $S$, Bonardi $R$, Cataliotti $L$, et al: Phyllodes tumor of the breast: A multicenter series of 59 cases. Eur J Surg Oncol 18: 545549, 1992

6) Salvadori B, Cusumano F, Del Bo R, et al: Surgical treatment of phyllodes tumors of the breast. Cancer 63: 2532-2536, 1989

7) Norris HJ, Taylor HB: Relationship of histologic features to behavior of cystosarcoma phyllodes: Analysis of ninety-four cases. Cancer $20: 2090-2099,1967$

8）日本乳癌学会：乳癌取扱い規約. 第12版, 金原出 版, 東京, 1996 
9) Hanada M, Maeda T, Takeuchi N : Cystosarcoma phyllodes of the breast with features of malignant fibrous histiocytoma. Acta Pathol Jpn $30: 91-99,1980$

10）清松釉一郎, 青柳和彦, 岩田正一郎他：悪性線維性 組織球腫の像を呈した悪性葉状萁胞肉腫の 1 例. 外科治療 $50: 385-388,1984$

11) Mentzel T, Kosmehl H, Katenkamp D: Metastasizing phyllodes tumour with malignant fibrous histiocytoma-like areas. Histopathology 19:557-560, 1991

12) Burton GV, Hart LL, Leight GS Jr, et al : Cystosarcoma phyllodes, Effective therapy with cisplatin and etoposide chemotherapy. Cancer 63 : 2088-2092, 1989

13) Ward RM, Evans HL: Cystosarcoma phyllodes: A clinicopathologic study of 26 cases. Cancer 58 : 2282-2289, 1986

14) Lindquist $\mathrm{KD}$, van Heerden JA, Weiland LH, et al: Recurrent and metastatic cystosarcoma phyllodes. Am J Surg 144: 341-343, 1982

15) El-Naggar AK, Ro JY, Mclemore D, et al: DNA content and proliferative activity of cystosarcoma phyllodes of the breast. Am J Clin Pathol $93: 480-485,1990$

16) Rossen K, Stamp I, Sorensen IM : Primary malignant fibrous histiocytoma of the breast, $A$ report of four cases and review of the literature. APMIS 99:696-702, 1991

17) Noguchi S, Aihara $T$, Motomura $K$, et al: Phyllodes tumor of the breast: Pathology, histogenesis, diagnosis, and treatment. Breast Cancer 3 : 79-92, 1996

\title{
A CASE OF RECURRENT MALIGNANT PHYLLODES TUMOR OF THE BREAST WITH FEATURES OF MALIGNANT FIBROUS HISTIOCYTOMA
}

\author{
Ikuo KOKUFU, Masayuki YAMAMOTO, Yosuke AKIYAMA, Katsumi YAMADA, \\ Hirofumi HIRAI and Hidetake KITANO \\ Department of Surgery, Itami City Hospital
}

We have encountered a rare case of recurrent malignant phyllodes tumor of the breast with features of malignant fibrous histiocytoma.

A 53-year-old woman underwent a resection and transposition of the latissmus dorsi muscle for a benign phyllodes tumor in the breast. Three months later, a painful induration was observed into the wound. Fine-needle aspiration cytology was carried out three times and showed only blood. There was a suspicion of hematoma on ultrasonography and computed tomography. Soon, redness and induration at the punctured skin were observed and thus a biopsy was conducted. Moderate mitotic activity and stromal atypia were revealed and the tumor was diagnosed as borderline phyllodes tumor. Clinically, infiltration into the pectralis major muscle was suspected, and a mastectomy was added to the patient. Histopathologically, spindle shaped cells were arranged in a storiform pattern and tumor cells were pleomorphic with benign duct epithelium. Cellularity and mitotic activity were considered high. The tumor was diagnosed as malignant phyllodes tumor with features of malignant fibrous histiocytoma. Pathological fracture of the humerus occurred 3 months after the operation and metastases to the lung and liver were found. The patient did not respond to chemotherapy and died 8 months after the operation. 